\title{
Real earnings manipulation surrounding mergers and acquisitions: The targets' perspective
}

Purpose: This paper investigates whether UK public targets manage their earnings using real activities manipulation in the period prior to the announcement of a merger and acquisition (M\&A). It also examines whether the payment method in M\&As affects the degree to which takeover targets manipulate earnings.

Design/methodology/approach: Using a sample of 131 UK listed targets acquired over the period 1995-2013, this paper examines real earnings management (REM) by employing OLS regression models. The data related to deals have been mainly collected from Thomson One Banker and Thomson Reuters Eikon databases. Real earnings management is examined by investigating abnormal cash flow from operations, abnormal discretionary expenses and abnormal production costs. This analysis was supplemented by conducting additional robustness checks.

Findings: The results show that UK takeover targets manage earnings upwards through cutting discretionary expenses in the year prior to the acquisition, while they do not do so by manipulating sales or production costs. Moreover, targets of cash-only or mixed-payment deals do not have the same strong motivation to manage their earnings as stock-financed deal target counterparts do. Our results continue to hold after using alternative accrual earnings management measures, controlling for unobservable firm heterogeneity using the fixed-effect model, and controlling for endogeneity using the two-stage Heckman (1979) model.

Originality: As far as the literature on earnings management (EM) around M\&As is concerned, only accruals earnings management by acquirers has been examined, and not much attention has been paid to targets' EM.

Practical implications: The main findings of this study could be beneficial for various parties involved M\&As, such as standard setters and regulators. A need arises to improve disclosure rules and enhance overall financial reporting quality in the capital markets with the aim of reducing information asymmetry and agency conflicts.

Keywords: Mergers and Acquisitions, Real Earnings Management, Cash-Only Deals, MixedPayment Deals, Stock-Financed Deals

Paper type: Research paper 


\section{Introduction}

Mergers and Acquisitions (M\&As) are amongst the most significant strategic investment decisions (SIDs) that firms make (Elmassri et al., 2016). One of the major financial practices within the M\&As context is earnings management (EM), since it may have a significant economic impact on the associated wealth transfers among stakeholders (e.g. Botsari and Meeks, 2008). Prior literature on EM demonstrates that managers may engage in two primary forms of EM, namely, accrual-based earnings management (AEM) and real earnings management (REM). In contrast to AEM, in which managers adjust assumptions, estimates and choices within the accounting system, REM involves the timing and structuring of normal business activities to achieve a favourablyperceived and desired financial reporting result (Kothari et al., 2016; Bereskin et al., 2018). Although AEM has been the primary practice addressed in the EM literature (Dechow et al., 2010; Fang et al., 2016; Lo et al., 2017), recent research shows an increased interest in understanding the role of REM (Campa and Hajbaba, 2016; Bereskin et al., 2018), as chief financial officers would prefer to utilise REM activities rather than AEM to reach a certain earnings benchmark or target prior to M\&As (Graham et al., 2005).

Due to the opaque nature of REM, this paper proposes it as an alternative EM mechanism employed within an M\&A context. Since real activities manipulation is subject to lower scrutiny from standard setters, regulators and external auditors (Kothari et al., 2016), we argue that managers of takeover targets may prefer to rely more on REM rather than AEM, especially in the final year prior to the announcement of the deal. Takeover targets are fully aware of the possibility that acquirers may demand a lowering of the consideration paid or even cancel the deal if aggressive accruals manipulation is detected. Therefore, reliance on accruals manipulation to inflate earnings may be risky for the target firm.

As far as the literature on EM around M\&As is concerned, AEM by acquirers has been examined (e.g., Botsari and Meeks, 2008; Higgins, 2013; Kassamany et al., 2017), and not much attention has been paid to targets' EM. Prior studies that examine EM by targets find mixed evidence as to the presence of such manipulation in the period prior to the announcement of the deal, which does not present convincing and persuasive reasons to challenge the presence of EM by takeover targets. For example, prior literature finds positive but insignificant earnings manipulation by targets (Erickson and Wang, 1999), positive evidence of earnings management in 
the case of hostile, as opposed to friendly takeovers (Easterwood, 1998), and positive earnings management by target firms acquired via auction vs. negotiation (Anilowski et al., 2009). Other studies find evidence of income-decreasing earnings management by targets of friendly acquisitions to facilitate the deal (Ben-Amar and Missonier-Piera, 2008) and report better financial results post-acquisition (Eddey and Taylor, 1999).

Based on the opaque nature of REM and the difficulty in distinguishing such practices from 'normal' rational business decisions, managers may have a preference to utilise such practices in times of heightened scrutiny, such as prior to M\&A transactions (Cohen et al., 2008; Zang, 2012). Accordingly, we examine REM practices employed by takeover targets' as they may be as equally motivated as acquirers to manipulate earnings prior to an acquisition

Additionally, we extend the literature on M\&As by examining the method of payment used in the deal. The consideration agreed upon by acquirers and targets may take various forms: pure cash, a pure share payment, and a mixture (hybrid) of both cash and stock (Alexandridis et al., 2011; DePamphilis, 2017). Prior literature finds that stock-for-stock acquirers manage their earnings by presenting unusually high levels of credit sales and overproduction in the quarter immediately before the merger announcement (Chang and Pan, 2020). Previous studies that examine the relationship between REM and payment consideration from the target firms' side are underrepresented. However, we argue that it is worth examining this relationship since there are reasonable and warranted motivations for target firms to manage their earnings. Target firms may attempt to use income-increasing earnings management strategies in order to offset any overvaluation present in the acquiring firm's stocks, with the aim of enhancing the exchange ratio (Erickson \& Wang, 1999). Furthermore, target firms may perceive a deal structured in the form of a stock acquisition as a riskier venture as opposed to its cash counterpart, which may lead the target to place a lower value as a response to the greater degree of uncertainty inherent in a purely stockfinanced deal (Martin, 1996). In addition, most prior studies are based on the US context (e.g., Easterwood, 1998; Eddey and Taylor, 1999; Erickson and Wang, 1999; Anilowski et al., 2009; Anagnostopoulou and Tsekrekos, 2013; Anagnostopoulou and Tsekrekos, 2015). Moreover, empirical evidence on acquisition targets and earnings management has been rather contextual or setting-specific and not so clearly directional, depending, for example, on whether the acquisition is friendly or not (e.g., Ben-Amar and Missonier-Piera, 2008; Easterwood, 1997), or takes place 
via an auction as opposed to negotiation (Anilowski et al., 2009). Similar to the US market for corporate control, UK M\&As represent an interesting setting in which UK takeover targets are as equally motivated as their US counterparts to manage earnings prior to an acquisition. The UK and US markets are similar in being large developed stock markets characterised by strong investor rights (La Porta et al., 1997; La Porta et al., 1999). Nevertheless, Ball et al. (2000) find that in comparison to other common-law countries such as: Australia, Canada, and the USA, the UK is characterised by a lower degree of litigation costs and political intervention in accounting. Similarly, Seetharaman et al. (2002) find that company directors in the UK are exposed to lower litigation risks as compared to their counterparts in the USA and other Anglo-Saxon countries.

Moreover, other studies such as Coffee (2005) document differences between the US and UK in terms of regulations and corporate governance; accordingly, it can be argued that earnings management may be different between these two countries. Based on the preceding discussions, the main aim of this study is to address the following questions:

- Whether UK publicly listed targets manage their earnings using real activities manipulation in the first year with an earnings release prior to the announcement of a M\&A?

- Whether the method of payment in a M\&A affects the degree to which takeover targets manipulate earnings?

This paper contributes to the literature on earnings management in the context of M\&As through focusing on the targets' side; by examining REM in the UK as an alternative manipulation strategy employed prior to a takeover. As far as the literature on EM around UK M\&As is concerned, only accruals earnings management by acquirers has been examined, and not much attention has been paid to UK targets' EM. Additionally, we examine the motivation of targets for preferring a specific payment method to manage their earnings.

The paper proceeds as follows: Section two introduces the study's theoretical framework and develops the research hypotheses. Section three presents details of the sample selection process and describes the methodology and empirical models. Section four discusses the empirical results. Section five provides additional robustness analyses. Section 6 concludes the paper and highlights its main implications and limitations. 


\section{Theoretical Framework, Literature Review and Hypotheses Development}

\subsection{Theoretical Framework}

A theoretical framework for earnings management is crucial for the current study since it facilitates the interpretation of the findings which will be assessed against the research questions and hypotheses. EM has been examined from various theoretical lenses, for instance, agency theory. Based on agency theory, there are two competing views of EM. The first view perceives that earnings management can be used opportunistically by managers to obtain private gains and maximise their own wealth, which consequently leads to negative consequences for shareholders. In this case, the discretion available to managers over accounting methods allows mangers to benefit themselves at the expense of various stakeholders (Watts and Zimmerman, 1990). It is assumed under the opportunistic perspective of earnings management that a higher degree of earnings management may be present in firms where agency costs are more severe, thus implying a positive relationship between earnings management and agency costs. The second view perceives earnings management being beneficial, in that managers have access to low-cost private information which they can communicate to shareholders and other external parties, in an attempt to improve the informative value of earnings, hence named the 'information perspective' of earnings management (e.g., Gunny, 2010).

As opposed to agency theory, stewardship theory suggests that managers have incentives to enhance the value of their firms in alignment with the wealth maximisation objective of shareholders. According to stewardship theory, managers are viewed as stewards of the company acting in the best interests of the shareholders setting aside any personal motivations or incentives in fulfilling their stewardship role (Albrecht et al., 2004). Under the propositions of this theory, managers are assumed to act in a non-opportunistic manner with an aim to perform a beneficial role leading to shareholders wealth maximisation, and in doing so, acting as good stewards. Davis et al., (1997, p.21) define stewardship theory as "Stewardship theory defines situations in which managers are not motivated by individual goals, but rather are stewards whose motives are aligned with the objectives of their principals". An interesting distinction between stewardship theory and agency theory lies in the degree that managers need to be monitored and controlled in their actions. Agency theorists view managers as self-serving and self-centred agents, who have great incentives to act in their own interests thus requiring a great deal of monitoring and control. 
On the contrary, stewardship theorists view the agent's actions stemming from the agent's role as a steward motivated to act in the best interest of the organisation as a whole. hypotheses.

Based on the aforementioned underpinning theories, the next section develops the research

\subsection{Takeover Targets and REM}

The literature on earnings management by targets in M\&As finds mixed evidence as to the presence of such manipulation in the periods prior to the announcement of the deal. This may seem quite strange, given that a target may be as equally motivated as an acquirer to manipulate earnings prior to an acquisition. For example, prior literature finds positive but insignificant earnings manipulation by targets (Erickson and Wang, 1999), positive evidence of earnings management in the case of hostile, as opposed to friendly takeovers (Easterwood, 1998), and positive earnings management by target firms acquired via auction vs. negotiation (Anilowski et al., 2009). Other studies find evidence of income-decreasing earnings management by targets of friendly acquisitions in order to facilitate the deal (Ben-Amar and Missonier-Piera, 2008), and report better financial results post-acquisition (Eddey and Taylor, 1999). As presented, prior literature around earnings management in M\&As finds mixed evidence as to whether takeover targets manipulate earning prior to a deal. Nevertheless, this does not present convincing and persuasive reasons to undermine the presence of earnings management by takeover targets.

Another stream of research examines the relationship between EM and various themes in accounting literature. For instance, the relationship between EM and equity incentives (Alhadab and Al-Own, 2019), audit quality (Astami et al., 2017), ownership structure (Alzoubi, 2016), national economic programmes (Hao et al., 2019), accounting methods (Lee and Choi, 2016), corporate social responsibility (Liu and Lee, 2019), reporting fraud (Ali et al., 2018), global financial crisis (Xu et al., 2016), capital investment decisions (Wang et al., 2010).

Prior literature on earnings management documents several differences between accrual based and real activities earnings management strategies in terms of when the manipulation takes place, the level of scrutiny by auditors and regulators, and the impact on current and/or future cash flows (Alhadab et al., 2016; Cohen et al., 2008; Cheng and Warfield, 2005). As opposed to real activities manipulation, accruals manipulation has no direct impact on cash flows and is considered 
less destructive to a firm's long-term value (Roychowdhury, 2006). However, accruals manipulation is subject to more scrutiny from standard setters, regulators, and external auditors (Kothari et al., 2016; Walker, 2013; Cohen and Zarowin, 2010; Roychowdhury, 2006; Graham et al., 2005).

REM is viewed as a "purposeful action to alter reported earnings in a particular direction, which is achieved by changing the timing and structuring of an operation, investment and financing transactions and which has suboptimal business consequences" (Zang, 2012, p.676). Although EM via accruals does not impose threats to a manipulating firm's cash flows, it may pose a threat to shareholders' trust in the managers of the firm, especially in cases of aggressive AEM ( Roychowdhury, 2006; Erickson et al., 2016; Kothari et al., 2016). In a survey of 169 chief financial officers of public companies, Dichev et al. (2013) find evidence suggesting that around 50 per cent of earnings quality is driven by non-discretionary factors such as industry factors. Thus, chief financial officers perceive REM as a more desirable earnings management mechanism due to its opaque nature, and the difficulty outsiders face in unravelling real activities manipulation. In addition, managers prefer to adopt REM practices as they are difficult to detect, since not every departure from normal business operations implies a case of real-activities manipulation (Commerford et al., 2016).

REM is focused primarily on managerial decisions that deviate from actual and normal business actions, Managers have flexibility in deciding the timing and extent of such actions with little interference and scrutiny from auditors, analysts, regulators, etc. (Cohen et al., 2008; Graham et al., 2005). Accordingly, a group of studies examine the timing at which mangers choose to manage earnings in a M\&A. Erickson and Wang (1999) argue that in order to maximise the benefits gained from managing earnings in the pre-merger period, managers would attempt to manipulate earnings in the periods with an earnings release preceding the announcement of a deal, and particularly the most recent period before the announcement of the deal.

Based on the discussions above, it is argued that takeover targets may use real activities manipulation as an EM tool especially in the first year prior to the deal announcement. In other words, if managers do indeed manipulate earnings, it follows that they are more likely to do so using strategies that have a low probability of detection, namely, through REM (Kothari et al., 2016). It is also assumed here that management has exhausted all attempts of accruals manipulation 
in the years leading up to the year of acquisition (year T-1); thus it would be very improbable that any additional aggressive accruals manipulation would remain undetected by the acquiring firm and its advisors (Barton and Simko, 2002). Therefore, management of a takeover target is expected to employ REM throughout the fiscal period.

Additionally, from a stewardship theory perspective, a target's management team may perceive that manipulating earnings prior to the deal would maximise their shareholders' gains from the deal, in a sense that they are fulfilling their fiduciary duties towards these shareholders. Indeed, prior literature finds empirical evidence that target shareholders greatly benefit from takeovers in the form of deal premiums (e.g., Antoniou et al., 2008; Chow et al., 2016). Hence, we formulate the following hypothesis in its alternative form:

H1: Takeover targets manage their earnings using real activities manipulation in the first year with an earnings release prior to the announcement of a takeover.

\subsection{REM and Consideration Method}

Prior literature finds empirical evidence that targets' shareholders greatly benefit from takeovers in the form of deal premiums (e.g., Goergen and Renneboog, 2004; Antoniou et al., 2008; Chow et al., 2016). Accordingly, a target firm aiming to maximise shareholders' wealth subsequent to the merger should avoid share-for-share bids. In addition, previous studies find evidence that markets react more favourably towards announcements of cash deals as opposed to share financed deals and premiums offered to target firms are lower in stock financed deals (Skaife and Wangerin, 2013; Raman et al., 2013; Marquardt and Zur, 2014). As such, instead of rejecting a share-for-share bid, a target firm may manage its earnings with the aim of extracting a more favourable deal with a higher premium for its shareholders.

Accordingly, target firms subject to a cash financed deal do not have the same strong motivation to manage their earnings as their counterparts do in a stock financed deal. This study does not rule out a prediction of earnings management by targets of cash-financed deals per se; the argument here is that targets would be more sceptical of stock financed deals as compared to cash deals, which should reduce their motivation to manage earnings. 
Based on stewardship theory, a target firm aiming to maximise shareholders' wealth subsequent to the merger should avoid share-for-share bids, since prior literature finds evidence that the market reacts more favourably to announcements of cash deals as opposed to share financed deals and premiums offered to targets are lower in stock financed deals (e.g., Anilowski et al., 2009). Consequently, following the discussions above, by partitioning the sample of takeover targets in the study according to the method of consideration (cash only, mixed payment, stock only) the following hypotheses are stated in their alternative form:

H2a: Takeover targets subject to a pure stock acquisition manage their earnings using real activities manipulation in the first year with an earnings release prior to the announcement of a takeover.

H2b: Takeover targets subject to pure cash or mixed consideration acquisition do not manage their earnings using real activities manipulation in the first year with an earnings release prior to the announcement of a takeover.

\section{Research Methodology and Design}

\subsection{Sample and Data Collection}

The sample used in this study is $131 \mathrm{UK}$ publicly listed targets acquired between the year 1995 and year 2013. Following prior studies (e.g., Raman et al., 2013; Vasilescu and Millo, 2016), a target is included in the sample if the deal is completed and if the acquirer acquires (or ends up holding) a majority interest in the target company. Also, no restriction was applied on the payment method of M\&A deals to test the earnings management hypothesis when the sample is partitioned according to the payment method.

EM is examined for each target in the sample in the three years with an earnings release preceding the year in which the deal was announced. As a starting point, Thomson One Banker® and Thomson Reuters Eikon® databases are used to collect all deal data including the deal values, consideration structure, announcement date, listing status, SIC codes, DataStream codes, deal premium and other details of the transaction. Further, EM and other annual accounting data are

extracted from DataStream ${ }^{\circledR}$, WorldScope (WS) and FAME®. The following table summarises 
the relevant criteria for sample selection discussed above as from the Thomson One Banker® (cross-checked with Eikon® M\&A) database:

[Insert Table (I)] 


\subsection{Measurement of Dependent Variable- REM}

Following prior research, we use three different measures to detect real earnings management (e.g., Roychowdhury, 2006; Cohen and Zarowin, 2010; Gunny, 2010; Zang, 2012;

Kothari et al., 2016). Specifically, the following three measures are used in the empirical model to examine the presence of real earnings management: abnormal cash flows from operations $\left(A B N \_C F O\right)$, abnormal discretionary expenses $\left(A B N \_D S X\right)$, and abnormal production costs $\left(A B N \_P R D\right)$.

\subsubsection{Measurement of Abnormal Cash Flows from Operations (ABN_CFO):}

Following Roychowdhury (2006) we estimate the normal level of cash flow from operations (CFO) using the following cross-sectional regression for each year and industry. The normal level of CFO is determined for each industry/year portfolio based on a two-digit SIC code classification with a minimum of six observations/peers by using a control sample comprising all UK publicly listed firms, excluding the target firms in the sample under study. All industry-year portfolios with less than six constituents in any given year are excluded from the analysis.

$$
\frac{\mathrm{CFO}_{\mathrm{it}}}{\mathrm{A}_{\mathrm{it}-1}}=\alpha_{0}+\alpha_{1}\left(\frac{1}{\mathrm{~A}_{\mathrm{it}-1}}\right)+\beta_{1}\left(\frac{\mathrm{S}_{\mathrm{it}}}{\mathrm{A}_{\mathrm{it}-1}}\right)+\beta_{2}\left(\frac{\Delta \mathrm{S}_{\mathrm{it}}}{\mathrm{A}_{\mathrm{it}-1}}\right)+\varepsilon_{\mathrm{it}}
$$

where:

$$
\begin{array}{ll}
\mathrm{A}_{\mathrm{t}-1} & =\text { total assets at the end of the prior year; } \\
\mathrm{S}_{\mathrm{i}, \mathrm{t}} & =\text { sales revenue at year } \mathrm{t} \text { for firm } \mathrm{i} ; \\
\varepsilon_{\mathrm{it}} & =\text { the error term; } \\
\mathrm{CFO}_{\mathrm{i}, \mathrm{t}} & =\text { cash flow from operations for firm } \mathrm{i} \text { at period } \mathrm{t} .
\end{array}
$$

Accordingly, abnormal cash flow from operations (ABN_CFO) for a target firm is the difference between actual CFO and the normal level of CFO as calculated using the estimated coefficients from the above regression model. All variables are scaled by lagged total assets to reduce heteroscedasticity.

\subsubsection{Measurement of Abnormal Discretionary Expenses (ABN_DSX):}

Discretionary expenses represent the sum of research and developed (R\&D), selling, general and administrative (SG\&A) and advertising expenditures. Reducing discretionary 
expenses such as R\&D, advertising expenses, and SG\&A would lead to an increase in reported earnings for the period (Zang, 2012). The normal level of discretionary expenses is estimated using the following cross-sectional regression for each industry/year portfolio.

$$
\frac{\text { DISEXP }_{i t}}{A_{i t-1}}=\alpha_{0}+\alpha_{1}\left(\frac{1}{A_{i t-1}}\right)+\beta\left(\frac{S_{i t-1}}{A_{i t-1}}\right)+\varepsilon_{i t}
$$

where:

DISEXP $_{\mathrm{i}, \mathrm{t}}=$ sum of R\&D, SG\&A; and advertising expenses for firm $i$ at period $t$.

$\mathrm{A}_{\mathrm{t}-1} \quad=$ total assets at the end of the prior year.

$\mathrm{S}_{\mathrm{i}, \mathrm{t}-1} \quad=$ sales revenue at the beginning of year $\mathrm{t}$ for firm $\mathrm{i}$.

$\mathrm{e}_{\mathrm{it}} \quad=$ the error term.

Accordingly, the abnormal level of discretionary expenses (ABN_DSX) for a target firm is the difference between actual discretionary expenses and the normal level of discretionary expenses as calculated using the estimated coefficients from the above regression model.

\subsubsection{Measurement of Abnormal Production Costs (ABN_PRD):}

Following Roychowdhury (2006), the normal level of production costs is estimated using the following cross-sectional regression for each industry/year portfolio with a minimum of six observations/peers by using a control sample comprising all UK publicly listed firms excluding the target firms in the sample under study.

$$
\frac{\text { PROD }_{i t}}{A_{i t-1}}=\alpha_{0}+\alpha_{1}\left(\frac{1}{A_{i t-1}}\right)+\beta_{1}\left(\frac{S_{i t}}{A_{i t-1}}\right)+\beta_{2}\left(\frac{\Delta S_{i t}}{A_{i t-1}}\right)+\beta_{3}\left(\frac{\Delta S_{i t-1}}{A_{i t-1}}\right)+\varepsilon_{i t}
$$

where:

PROD $_{\mathrm{i}, \mathrm{t}}=$ the sum of cost of goods sold in year $\mathrm{t}$ and the change in inventory from $\mathrm{t}-1$ to $\mathrm{t}$;

$\mathrm{A}_{\mathrm{t}-1} \quad=$ total assets at the end of the prior year.

$\mathrm{S}_{\mathrm{i}, \mathrm{t}-1} \quad=$ sales revenue at the beginning of year $\mathrm{t}$ for firm $\mathrm{i}$.

$\mathrm{e}_{\mathrm{it}} \quad=$ the error term. 
Accordingly, the abnormal level of production costs (ABN_PRD) for a target firm is the difference between actual production costs and the normal level of production costs as calculated using the estimated coefficients from the regression model.

\subsection{Research Model}

The model for each real earnings management measure is run separately with similar independent explanatory variables and various control variables as presented in equation (4). The model is run separately for each real earnings management proxy to test H1. Additionally, the model is estimated separately for the different target groups stratified by the method of payment in the deal to test hypotheses $\mathrm{H} 2 \mathrm{a}$ and $\mathrm{H} 2 \mathrm{~b}$.

Based on prior literature on REM (e.g. Zalata et al., 2018; Bereskin et al., 2018), the empirical model controls for other firm-specific factors which have been shown to be associated with REM, such as size (FRMSIZE), return on assets (ROA), sales growth (SGROWTH) and the market-to-book ratio (MTB). In addition, equation (4) controls for the trade-off between real earnings management and accruals manipulation by including the signed value of lagged abnormal discretionary working capital accruals derived from the modified Jones (1995) model (AEM_CTRL). Further, all regression models are estimated while clustering at the 'target' firm

level to produce Rogers (1993) robust standard errors, which are heteroscedasticity and autocorrelation consistent.

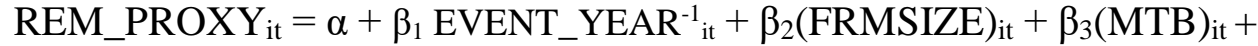

$$
\begin{aligned}
& \beta_{4}(\mathrm{ROA})_{\mathrm{it}}+\beta_{5}\left(\mathrm{AEM} \_\mathrm{CTRL}\right){ }_{\text {it }}+\beta_{6}(\mathrm{SGROWTH})+\varepsilon_{\mathrm{it}}
\end{aligned}
$$

where:

REM_PROXY = Real Earnings management proxy which takes one of three variables:

ABN_CFO: Abnormal cash flows from operations estimated using the Roychowdhury (2006) model.

$A B N \_D S X$ : Abnormal discretionary expenses estimated using the Roychowdhury (2006) model.

$A B N \_P R D$ : Abnormal production costs estimated using the Roychowdhury (2006) model.

$E V E N T_{-} Y E A R^{-1}=$ A dummy variable that takes the value of 1 for the first year preceding the acquisitio and zero otherwise 


$\begin{array}{ll}\text { FRMSIZE } & =\text { Firm size calculated as the natural logarithm of market } \\ & \text { capitalization } \\ & =\text { Market-to-book ratio calculated as the market value of common } \\ & \text { equity divided by the book value of common equity } \\ & =\text { Return on assets calculated as net income before extraordinary } \\ & \text { items divided by lagged total assets } \\ & =\text { Signed abnormal discretionary working capital accruals derived } \\ \text { AEM_CTRL } & \text { from the modified Jones model to control for the trade-off between } \\ & \text { AEM and REM } \\ \text { SGROWTH } & =\text { One-year growth in sales } \\ \varepsilon & =\text { Error term } \\ i & =\text { Firm subscript } \\ t & =\text { Time subscript }\end{array}$

\section{Empirical Results and Discussion}

The following sub-sections present the results derived from estimating the real earnings management empirical models. Each real earnings management model is estimated for each industry-year portfolio to derive the parameter estimates, which are later combined with target firm-specific data to determine the normal levels of cash flows from operations, discretionary expenses and production costs.

\section{4..1 Descriptive Statistics and Univariate Analyses}

Table (II) presents descriptive statistics for the three real earnings management proxies used in the empirical analyses for the overall pooled sample of targets and subsamples stratified by method of payment used in the deal. The descriptive statistics and univariate analysis provide preliminary evidence in support of hypotheses $\mathrm{H} 2 \mathrm{a}$ and $\mathrm{H} 2 \mathrm{~b}$. Unlike targets subject to non-stock acquisitions, which have a negative mean (-0.056) of abnormal discretionary expenses (ABN_DSX), targets acquired in stock-financed deals display a positive mean for abnormal discretionary expenses of around $4.7 \%$ of total assets. This preliminary finding is consistent with the earnings management hypothesis that targets of stock-financed deals are more motivated than their cash-financed counterparts to manage earnings prior to the acquisition, as signalled by a higher magnitude of cuts in discretionary expenses. This initial finding indicates that targets of stock-financed deals cut their discretionary expenses in the periods leading up to the announcement of the deal to manage their earnings upwards, and from a stewardship theory perspective, extract a higher premium for their shareholders perhaps. 
For abnormal cash flows from operations (ABN_CFO), the differences in mean and median values are statistically insignificant, suggesting that takeover targets, irrespective of the consideration structure in the deal, do not manipulate their sales prior to the acquisition. For abnormal production costs, although the difference in means is statistically insignificant between the two groups, the Wilcoxon signed-rank $\mathrm{Z}$ test indicates a statistically significant difference in medians. Targets of non-stock financed deals display a higher magnitude of abnormal production costs relative to the rest of the sample. Nevertheless, this discrepancy between reported means and medians is due to the non-normal distribution of the various real earnings management metrics used in the univariate analysis. As for the negative mean abnormal production costs for the stockonly group of targets (mean value of -0.062), this finding initially indicates that overproduction as a real earnings management tool is perceived as a less favourable manipulation tool by this group of targets. It is argued here that overproduction as a real earnings manipulation tool is less convenient due to a lower degree of managerial discretion as compared to cutting selling, advertising, and administrative expenses, for example.

\section{[Insert Table (II)]}




\subsection{Takeover Targets' Abnormal Cash Flows from Operations}

Panel A of Table (III) reports the empirical results for the abnormal cash flows from operations (ABN_CFO) model for a sample of targets as estimated using equation (4). Specifically, to test $H 1$, abnormal cash flows from operations (ABN_CFO) is used as the dependent variable in the models and the main explanatory variable of interest is EVENT_YEAR${ }^{1}$. Similarly, hypotheses $\mathrm{H} 2 \mathrm{a}$ and $\mathrm{H} 2 \mathrm{~b}$ are examined by the sign and significance of the coefficient when the model is re-run separately for targets involved in pure cash acquisitions, pure stock acquisitions, and targets of mixed payment deals.

As shown in Panel A of Table (III), across all models, the coefficient on the main explanatory variable EVENT_YEAR ${ }^{-1}$ is statistically insignificant. These results imply that takeover targets do not manage their earnings through sales manipulation in the first period with an earnings release prior to the announcement of the deal, and as such, hypothesis $\mathrm{H} 1$ is rejected. These results are not consistent with those of Campa and Hajbaba (2016), who find evidence indicating that US target companies acquired in the period from 2001 to 2011 exhibit lower cash flows from operations (upwards sales manipulation) in the first year before the acquisition, given a similar level of sales than the years before, but only for cash-acquired targets. Nevertheless, Campa and Hajbaba (2016) do not attempt to partition their sample of targets into three subsamples as in this study, hence their results may be interpreted differently.

An explanation in support of the results presented in Panel A of Table (III) is that firms aiming to manipulate their earnings upwards by utilising real earnings management tools are likely to choose between either sales manipulation or a cut in discretionary expenses, but not both. This is due to the fact that accelerating sales would generally require a higher level of selling, general, and administrative expenses. It follows that, if a target firm attempts to use both real activities manipulation tools (i.e., accelerating sales and cutting discretionary expenses) together, it may attract the attention of auditors, analysts, and the due diligence team employed by the acquirer, who may suspect that the target's management team are using these methods more extensively than usual. As a result, an acquirer may deem such actions as suboptimal decisions solely undertaken to manipulate earnings; in response, the acquirer may terminate the deal or lower the consideration paid. As such, the empirical results for the abnormal cash flows model should be considered alongside the results reported for models of abnormal production costs and abnormal discretionary expenses which are reported in the following sections. 
In terms of control variables, the results are generally consistent with findings in the prior literature. More specifically, sales growth (SGROWTH), market-to-book ratio $(M T B)$, firm performance $(R O A)$, and the AEM control variable measure (AEM_CTRL) display statistically significant coefficient estimates. However, the results reported in Panel A of Table (III) do not indicate any statistically significant coefficient estimates for the control variable SIZE, consistent with the findings of Zang (2012). Finally, in line with prior research (Roychowdhury, 2006; Cohen et al., 2008; Cohen and Zarowin, 2010; Alhadab et al., 2016) a significant positive coefficient estimate is found for the AEM control variable AEM_CTRL, suggesting that target firms engage in accrual manipulation and real activities manipulation at the same time (Roychowdhury, 2006). In terms of sales growth (SGROWTH), results reported in Panel A of Table (III) show a significant positive relationship with abnormal cash flows from operations. In terms of profitability, Panel A of Table (III) reports a statistically negative association between ROA and abnormal cash flows from operations for most of the models at the $1 \%$ level. These results provide strong evidence that profitability is associated with low levels of earnings management (Keung and Shih, 2014; Cotten, 2008; Fan, 2007; Kothari et al., 2005; Kasznik, 1999; Jeter and Shivakumar, 1999). Collectively, the results presented in Panel A of Table (III) indicate that targets do not rely on sales manipulation as a real earnings management tool in the periods prior to the acquisition.

\subsection{Takeover Targets Abnormal Discretionary Expenses}

Panel B of Table (III) reports the results of estimating the multiple regression empirical model (4) using abnormal discretionary expenses to proxy for real earnings management. The results reported in Panel B of Table (III) provide evidence in support of the earnings management hypothesis from a stewardship theory perspective that targets of stock-financed M\&As manipulate their earnings using real earnings management in the first year prior to the announcement of the deal aiming to extract a higher return for their shareholders, providing evidence in support of hypothesis $\mathrm{H} 2 \mathrm{a}$. More specifically, the coefficient $\beta_{1}$ on the explanatory variable EVENT_YEAR ${ }^{-1}$ (column 2) is positive and statistically significant at the $5 \%$ level of significance $\left(\beta_{1}=0.084\right.$, t-statistic $\left.=2.66\right)$.

The statistically significant coefficient on the indicator variable (EVENT_YEAR ${ }^{-1}$ ) indicates that targets manipulate their earnings in the first year with an earnings release prior to the acquisition relative to other periods in the three-year event period under study. More specifically, the results indicate that mean abnormal discretionary expenses are higher by $8.4 \%$ 
of total assets in comparison with the previous periods. It is worth noting here that the results reported show that coefficient $\beta_{1}$ is statistically insignificant for the cash-only and mixedpayment target groups across all models and event years, hence providing evidence supporting hypothesis $\mathrm{H} 2 \mathrm{~b}$ of no earnings management by targets of these deals. These results are consistent with the findings of North and O’Connell (2002), Christie and Zimmerman (1994) and Easterwood (1998). Higgins (2013), Botsari and Meeks (2008) and Louis (2004) report similar results for acquiring firms ahead of M\&As. These findings are in line with the argument that targets of cash-only or mixed-payment deals do not have the same strong motivations to manage their earnings as their stock-financed deals counterparts do, additionally supporting the findings of prior studies that the method of payment in takeovers is value relevant (e.g., Hansen, 1987; Stulz, 1988; Fishman, 1988; Fishman, 1989; Martin, 1996; Faccio and Masulis, 2005; DePamphilis, 2017).

A statistically significant negative association is found between firm size and abnormal discretionary expenses for the overall sample of targets, whereas such an association is only specific to targets involved in stock-financed M\&As. This result is consistent with prior studies that find that firm size is a significant determinant of earnings management, since regulators and auditors are more sceptical of larger firms when investigating accounting irregularities management (e.g., Pham et al., 2017; Collins et al., 2017; Dechow and Dichev, 2002; Lee and Choi, 2002; Becker et al., 1998; Albrecht and Richardson, 1990; among others). Collectively, the results presented in Panel B of Table (III) provide evidence in support of hypotheses $\mathrm{H} 2 \mathrm{a}$ and $\mathrm{H} 2 \mathrm{~b}$ indicating that targets acquired in stock-financed deals cut selling, general, and administrative expenses in the first year prior to the acquisition and, thereby, manipulate their earnings upwards. Moreover, this finding is consistent with the univariate analysis results reported in Table (II), which displays statistically significant results for abnormal discretionary expenses as signalled by statistically significant t-test statistics and Wilcoxon rank-sum tests for the differences in mean and median between the different target subsamples.

\subsection{Takeover Targets Abnormal Production Costs}

Panel C of Table (III) reports the empirical results for the abnormal production costs (ABN_PRD) REM model. Reported results do not indicate any evidence supporting the earnings management hypothesis that targets engage in real earnings management by overproducing to report lower cost of goods sold. A possible explanation for the absence of any indication of real earnings management using overproduction may be that, if targets did indeed opt to use this tool 
to manipulate earnings, then they would need to commit additional resources in order to sustain such levels of abnormal production and the associated costs of managing excess merchandise. An alternative explanation for the insignificant results for abnormal production costs could be due to using production levels as a proxy for earnings management. Roychowdhury (2006) develops a model based on Dechow et al. (1998) to estimate the normal level of production costs defining production costs as the sum of cost of goods sold and changes in inventory throughout the year. However, using the sum of cost of goods sold and changes in inventory may lead to ambiguous results. In other words, production costs may lack potential to fully capture instances of over/under production. Collectively, the results presented in Panel C of Table (III) for the abnormal production costs model fail to yield any statistically significant evidence supporting the earnings management hypotheses.

The results of the real activities manipulation tests indicate that, on average, target firms manage earnings upwards through abnormal cuts to discretionary expenses such as SG\&As in the year before the acquisition while they do not do so using sales manipulation or overproduction. These results are consistent with the findings of Cohen and Zarowin (2010) who find that in a similar capital market context, more precisely, within the context of seasoned equity offerings (SEOs), firms engage in REM during the offer year and that these activities have severe negative consequences for subsequent operating performance. More recently, Kothari et al. (2016) also find evidence that managers' propensity to engage in REM is greatly higher than the propensity to engage in accruals manipulation, despite the severe negative consequences of REM documented in the literature.

\section{[Insert Table III]}




\section{Robustness Check}

\subsection{Controlling for unobserved heterogeneity using the fixed effects estimator}

So far, in our main analysis, we have relied on using pooled data linear regressions. Additionally, we use discretionary current working capital accruals as estimated from the modified Jones (1995) model to proxy for AEM used in the empirical model to control for the trade-off between the two manipulation strategies. To check the robustness of our results, we use an alternative fixed-effects (FE) regression model that allows controlling for the impact of independent variables on the estimated coefficients, which mitigates the omitted (unobservable) variable effect on estimated coefficients. The results of these robustness tests are presented in table (IV). This table shows the results of the FE regression models while also using discretionary current accruals as estimated from the performance-adjusted accruals model (Kothari et al., 2005) as an alternative proxy for AEM in line with previous studies in the literature (e.g., Keung and Shih, 2014; Cotten, 2008; Fan, 2007; Kothari et al., 2005; Kasznik, 1999; Jeter and Shivakumar, 1999). Overall, the results presented in table (IV) are similar to previous results obtained in the main analysis. The coefficient on the main explanatory variable of interest EVENT_YEAR ${ }^{-1}$ (column 2) is positive and statistically significant at the1\% level. In conclusion, when we use alternative measures of accrual earnings management and control for unobservable firm heterogeneity by estimating a FE regression model, we obtain qualitatively similar results.

\section{[Insert Table (IV)]}

\subsection{Heckman two-step procedure to address endogeneity concerns}

Since M\&As are firms' decisions rather than a random assignment, our previous empirical models' coefficient estimation in section 3.3 can be subject to self-selection bias. To account for this possible endogeneity bias, we run the two-step estimation method developed by Heckman (1979). In particular, we include the inverse Mill's ratio (IMR), estimated from a probit model's coefficients on the likelihood of becoming an M\&A target, as an additional control variable in our previous empirical models. The probit model's dependent variable is a dummy that takes the value of one if a firm becomes a target in a given year and zero otherwise. Following Ahmed and Elshandidy (2020), explanatory variables in this model include firm size, ROA, market to book, market leverage, stock return, industry M\& A liquidity index, the Herfindahl index, and year and industry fixed effects. 
Table (V) shows that controlling for endogeneity bias using Heckman's method does not change our inferences that targets of stock-financed M\&As manipulate their earnings using real earnings management in the first year before the announcement of the deal. ${ }^{1}$ Overall, using Heckman's method confirms the robustness of the main results presented earlier and negates endogeneity concerns.

\section{[Insert Table (V)]}

\section{Conclusions}

The majority of studies examining earnings management ahead of M\&As focus on earnings manipulation strategies of the acquirer, finding that acquiring firms manage earnings upwards prior to stock-for-stock transactions in an effort to increase their stock price and reduce the number of shares issued in exchange (e.g., Erickson and Wang, 1999; Louis, 2004; Baik et al., 2007; Gong et al., 2008; Botsari and Meeks, 2008; Higgins, 2013; Kassamany et al., 2017). However, less attention has been paid to earnings management by targets and their motivations in doing so.

This paper examines EM by takeover targets in the first period with an earnings release prior to the announcement of M\&A deals. In analysing the EM behaviour of targets prior to the acquisition, we investigate various REM strategies and whether takeover targets use such earnings manipulation tools interdependently or mutually exclusive.

We find that, on average, takeover targets manage earnings upwards through cutting discretionary expenses in the year prior to the acquisition, while they do not do so by manipulating sales or production costs. Moreover, when we partition the sample of targets according to the method of payment used in the deal, the results apply only to targets of stock-financed deals. These results are consistent with the argument that targets of cash-only or mixed-payment deals do not have the same strong motivations to manage their earnings as their stock-financed deals counterparts do. Additionally, such evidence is in line with the perspective of stewardship theory. Collectively, the results contribute to the literature on the trade-off between different earnings management tools, indicating that takeover targets opt to use the most adequate approach depending on the timing of the acquisition. In terms of M\&As, takeover targets may refrain from using any accrual manipulation strategies, especially in the first year with an earnings release prior to the deal, assuming that the most recent earnings release would be subject to the highest degree of scrutiny and scepticism. It follows that, during such times of heightened scrutiny on the part of

\footnotetext{
${ }^{1}$ We get consistent results when we run Heckman (1979) two-step self-selection correction model on other empirical tables.
} 
the acquirer and its advisors, it is very unlikely that accrual-based earnings management would be a dominant on exclusive source of overvaluation prior to the deal (Cohen and Zarowin, 2010; Vasilescu and Millo, 2016; Kothari et al., 2016).

The main findings of this study could be beneficial for a vast array of users such as accounting standard setters, analysts, investors, policy makers, targets' shareholders, auditors and financial advisors. In terms of accounting standard setters and regulators, a need arises to improve disclosure rules and requirements and enhance overall financial reporting quality in the capital markets in order to reduce information asymmetry and agency conflicts between principals and agents. Accordingly, a more transparent disclosure system will help mitigate and hopefully prevent attempts of earnings management. Taking into account the negative consequences of earnings manipulation as documented in the literature on stock overvaluation in the capital market as a whole, and acquisition premia paid in M\&As, enhancing disclosure systems and accounting standards will help constrain accrual and real earnings management activities and, as such, alleviate the adverse effects of these manipulating strategies. Additionally, various parties involved in a M\&A such as financial analysts, financial advisors, targets' and acquirers' shareholders, and auditors need to be alert to the fact that managers have a vast array of manipulation strategies at their disposal, and, as such, be sceptical of not only accruals manipulation, but also real earnings management as a more opaque manipulation tool. Finally, this study provides evidence that targets of stock-financed deals are more motivated to manipulate their earnings as compared to their cash-only or mixed-payment financed deals counterparts do. Accordingly, the findings highlight the particulars that monitoring bodies should take into consideration when dealing with companies involved in M\&As conditional to the consideration structure used in the deal.

Despite the evidence documented in this study, and the broad array of earnings management proxies and robust analysis used to ensure validity of the results, there are a few limitations that need to be acknowledged, which provides avenues for future research. First, the earnings management models used in this study are employed in their cross-sectional form. A limitation of estimating the proxies used for REM cross-sectionally is that pooling data across industries to construct estimation portfolios may lead to misspecified tests. In other words, standard cross-sectional REM models rely on the assumptions of firm stationarity and intraindustry homogeneity. The inherent limitation here lies in the possibility that peer firms making up the control sample may not share the same level of homogeneity in terms of the accruals generating process. Accordingly, these models do not consider the fact that earnings are best 
described by dynamic processes, as stated by Gerakos (2012). As a proposed solution to such a limitation, future studies may use size-based control samples arguing for a better goodness of fit for the models, and more precise residual estimates (e.g., Ecker et al., 2013).

Additionally, further research can corroborate the findings of this study by simultaneously examining earnings management by acquirers and investigate whether such manipulation impacts earnings management by targets. Since this study does not, and cannot control for all possible incentives of managers to manipulate earnings, an equally plausible reverse causation interpretation may be that, rather than takeover targets managing earnings in anticipation of an impending acquisition, it may be argued that earnings management in itself acts as a signalling mechanism that attracts acquirers. In other words, acquirers operating in the same industry as targets may be fully aware of the accruals generating process of these target firms. Accordingly, acquirers can easily detect any earnings management by these targets, and, in response, attempt to takeover such firms. Finally, an interesting research topic here would be to simultaneously examine earnings management by targets of successful and unsuccessful M\&As and investigate whether both samples manipulate their earnings, and whether such manipulation, if documented, has an impact on the success rate of a M\&A. 


\section{References}

Ahmed,Y. and Elshandidy,T., (2020). Effect of leverage deviation on choices and outcomes of public versus non-public acquisitions. International Journal of Finance \& Economics.

Albrecht,W.D. and Richardson,F.M., (1990). Income Smoothing By Economy Sector. Journal of Business, Finance, and Accounting, 17(5), pp.713-730.

Albrecht,W.S., Albrecht,C.C. and Albrecht,C.O., (2004). Fraud and corporate executives: Agency, stewardship and broken trust. Journal of Forensic Accounting, 5(1), pp.109-130.

Alhadab,M., Clacher,I. and Keasey,K., (2016). A Comparative Analysis of Real and Accrual Earnings Management around Initial Public Offerings under Different Regulatory Environments. Journal of Business, Finance, and Accounting, 43(7-8), pp.849-871.

Alhadab,M., Clacher,I. and Keasey,K., (2015). Real and accrual earnings management and IPO failure risk. Accounting and Business Research, 45(1), pp.55-92.

Alhadab,M. and Al-Own,B., (2019). Earnings management and equity incentives: evidence from the European banking industry. International Journal of Accounting \& Information Management.

Ali,A. and Zhang,W.N., (2015). CEO tenure and earnings management. Journal of Accounting and Economics, 59(1), pp.60-79.

Ali,M.J., Razzaque,R.M.R. and Ahmed,K., (2018). Real earnings management and financial statement fraud: evidence from Malaysia. International Journal of Accounting \& Information Management.

Alzoubi,E.S.S., (2016). Ownership structure and earnings management: evidence from Jordan. International Journal of Accounting \& Information Management.

Anagnostopoulou,S.C. and Tsekrekos,A.E., (2013). Do firms that wish to be acquired manage their earnings? Evidence from major European countries. International Review of Financial Analysis, 30, pp.57-68.

Anagnostopoulou,S.C. and Tsekrekos,A.E., (2015). Earnings management in firms seeking to be acquired. The British Accounting Review, 47(4), pp.351-375.

Anilowski,C., Macias,A.J. and Sanchez,J.M., (2009). Target Firm Earnings Management and the Method of Sale: Evidence from Auctions and Negotiations. SSRN eLibrary.

Antoniou,A., Arbour,P. and Zhao,H., (2008). How Much is Too Much: Are Merger Premiums Too High? European Financial Management, 14(2), pp.268-287.

Astami,E.W., Rusmin,R., Hartadi,B. and Evans,J., (2017). The role of audit quality and culture influence on earnings management in companies with excessive free cash flow. International Journal of Accounting \& Information Management.

Baik,B., Kang,J.-K. and Morton,R.M., (2007). Earnings Management in Takeovers of Privately Held Targets. SSRN Electronic Journal.

Ball,R., Kothari,S.P. and Robin,A., (2000). The effect of international institutional factors on properties of accounting earnings. Journal of Accounting and Economics, 29(1), pp.1-51.

Ball,R. and Foster,G., (1982). Corporate financial reporting: A methodological review of empirical research. Journal of Accounting Research, pp.161-234. 
Barton,J. and Simko,P.J., (2002). The balance sheet as an earnings management constraint. The Accounting Review, 77(s-1), pp.1-27.

Becker,C.L., Defond,M.L., Jiambalvo,J. and Subramanyam,K.R., (1998). The effect of audit quality on earnings management. Contemporary Accounting Research, 15(1), pp.1-24.

Ben-Amar,W. and Missonier-Piera,F., (2008). Earnings management by friendly takeover targets. International Journal of Managerial Finance, 4(3), pp.232-243.

Bereskin,F.L., Hsu,P. and Rotenberg,W., (2018). The real effects of real earnings management: Evidence from innovation. Contemporary Accounting Research, 35(1), pp.525-557.

Bergstresser,D. and Philippon,T., (2006). CEO incentives and earnings management. Journal of Financial Economics, 80(3), pp.511-529.

Botsari,A. and Meeks,G., (2008). Do acquirers manage earnings prior to a share for share bid? Journal of Business, Finance, and Accounting, 35(July), pp.633-670.

Bozos,K., Ratnaike,Y.C. and Alsharairi,M., (2014). How has the international harmonization of financial reporting standards affected merger premiums within the European Union? International Review of Financial Analysis, 31, pp.48-60.

Braga-Alves,M. V, Ellis,J., Mandelker,G.N. and Zutter,C.J., (2009). The Effect of Takeover Probability on Earnings Management, Working Paper. Marquette University.

Campa,D. and Hajbaba,A., (2016). Do targets grab the cash in takeovers: The role of earnings management. International Review of Financial Analysis, 44, pp.56-64.

Chang,C.C. and Pan,H., (2020). How do stock-for-stock acquirers manage earnings? The accruals feature of real earnings management. Journal of Contemporary Accounting and Economics.

Cheng,Q. and Warfield,T.D., (2005). Equity Earnings Management. The Accounting Review, 80(2), pp.441-476.

Chow,T., Klassen,K.J. and Liu,Y., (2016). Targets' Tax Shelter Participation and Takeover Premiums. Contemporary Accounting Research, 33(4), pp.1440-1472.

Christie,A. a and Zimmerman,J.L., (1994). Efficient and Opportunistic Choices of Accounting Procedures: Corporate Control Contests. The Accounting Review, 69, pp.539-566.

Coffee,J., (2005). A theory of corporate scandals: Why the USA and Europe differ. Oxford review of Economic Policy, 21(2), pp.198-211.

Cohen,D., Dey,A. and Lys,T., (2008). Real and Accrual-based Earnings Management in the Preand Post-Sarbanes-Oxley Periods. The Accounting Review, 83(3), pp.757-787.

Cohen,D.A. and Zarowin,P., (2010). Accrual-based and Real Earnings Management Activities around Seasoned Equity Offerings. Journal of Accounting and Economics, 50, pp.2-19.

Collins,D.W., Pungaliya,R.S. and Vijh,A.M., (2017). The effects of firm growth and model specification choices on tests of earnings management in quarterly settings. The Accounting Review, 92(2), pp.69-100.

Commerford,B.P., Hermanson,D.R., Houston,R.W. and Peters,M.F., (2016). Real earnings management: A threat to auditor comfort? Auditing: A Journal of Practice and Theory, 35(4), pp.39-56.

Cotten,B.D., (2008). Earnings Management Prior to Initial Public Offerings: Evidence from 
Secondary Share Data. Quarterly Journal of Finance \& Accounting, 47(4), pp.87-107.

Davis,J.H., Schoorman,F.D. and Donaldson,L., (1997). Toward a Stewardship Theory of Management. Academy of Management Review, 22(1), pp.20-47.

Dechow,P., Ge,W. and Schrand,C., (2010). Understanding earnings quality: A review of the proxies, their determinants and their consequences. Journal of Accounting and Economics, 50(2-3), pp.344-401.

Dechow,P.M. and Dichev,I.D., (2002). The Qualityof Accruals and Earnings: The Role of Accruals Estimation Errors. The Accounting Review, 77, pp.35-59.

DePamphilis,D., (2017). Mergers, Acquisitions, and Other Restructuring Activities: An Integrated Approach to Process, Tools, Cases, and Solutions, Elsevier Science.

Dichev,I.D., Graham,J.R., Harvey,C.R. and Rajgopal,S., (2013). Earnings quality: Evidence from the field. Journal of Accounting and Economics, 56(2-3), pp.1-33.

Easterwood,C.M., (1998). Takeovers and Incentives for Earnings Management: An Empirical Analysis. Journal of Applied Business Research, 14(1), pp.29-48.

Ecker,F., Francis,J., Olsson,P. and Schipper,K., (2013). Estimation sample selection for discretionary accruals models. Journal of Accounting and Economics, 56(2-3), pp.190-211.

Eddey,P.H. and Taylor,S.L., (1999). Directors' Recommendations on Takeover Bids and the Management of Earnings: Evidence from Australian Takeovers. Abacus, 35(1), pp.29-45.

Elmassri,M.M., Harris,E.P. and Carter,D.B., (2016). Accounting for strategic investment decisionmaking under extreme uncertainty. The British Accounting Review, 48(2), pp.151-168.

Erickson,D., Hewitt,M. and Maines,L.A., (2016). Do investors perceive low risk when earnings are smooth relative to the volatility of operating cash flows? Discerning opportunity and incentive to report smooth earnings. The Accounting Review, 92(3), pp.137-154.

Erickson,M. and Wang,S., (1999). Earnings management by acquiring firms in stock for stock mergers. Journal of Accounting and Economics, 27(2), pp.149-176.

Faccio,M. and Masulis,R.W., (2005). The Choice of Payment Method in European Mergers and Acquisitions. The Journal of Finance, 60(3), pp.1345-1388.

Fan,Q., (2007). Earnings Management and Ownership Retention for Initial Public Offering Firms : Theory and Evidence. The Accounting Review, 82(1), pp.27-64.

Fang,V.W., Huang,A.H. and Karpoff,J.M., (2016). Short selling and earnings management: A controlled experiment. The Journal of Finance, 71(3), pp.1251-1294.

Fishman,M.J., (1988). A Theory of Preemptive Takeover Bidding. The Rand Journal of Economics, pp.88-101.

Fishman,M.J., (1989). Preemptive Bidding and the Role of the Medium of Exchange in Acquisitions. The Journal of Finance, 44(1), pp.41-57.

Gerakos,J., (2012). Discussion of detecting earnings management: A new approach. Journal of Accounting Research, 50(2), pp.335-347.

Goergen,M. and Renneboog,L., (2004). Shareholder Wealth Effects of European Domestic and Cross-Border Takeover Bids. European Financial Management, 10(1), pp.9-45. 
Gong,G., Louis,H. and Sun,A.X., (2008). Earnings management, lawsuits, and stock-for-stock acquirers' market performance. Journal of Accounting and Economics, 46(1), pp.62-77.

Graham,J.R., Harvey,C.R. and Rajgopal,S., (2005). The economic implications of corporate financial reporting. Journal of Accounting and Economics, 40(1-3), pp.3-73.

Gunny,K., (2010). The Relation Between Earnings Management Using Real Activities Manipulation and Future Performance: Evidence from Meeting Earnings Benchmarks. Contemporary Accounting Research, 27(3), pp.855-888.

Hansen,R.G., (1987). A Theory for the choice of exchange medium in mergers and acquisitions. Journal of Business, 60(1), pp.75-95.

Hao,Q., Shi,X., Bu,D. and Li,L., (2019). The impact of the Chinese stimulus program on earnings management. International Journal of Accounting \& Information Management.

Healy,P.M. and Wahlen,J.M., (1999). A review of the earnings management literature and its implications for standard setting. Accounting Horizons, 13, pp.365-383.

Heckman,J.J., (1979). Sample selection bias as a specification error. Econometrica: Journal of the econometric society, pp.153-161.

Higgins,H.N., (2013). Do Stock-for-Stock Merger Acquirers Manage Earnings? Evidence from Japan. Journal of Accounting and Public Policy, 32(1), pp.44-70.

Ipino,E. and Parbonetti,A., (2017). Mandatory IFRS adoption: the trade-off between accrual-based and real earnings management. Accounting and Business Research, 47(1), pp.91-121.

Jeter,D.C. and Shivakumar,L., (1999). Cross-sectional estimation of abnormal accruals using quarterly and annual data: Effectiveness in detecting event-specific earnings management. Accounting and Business Research, 29(4), pp.299-319.

Kassamany,T., Ibrahim,S. and Archbold,S., (2017). Accrual and real-based earnings management by UK acquirers: Evidence from pre-and post-Higgs periods. Journal of Accounting \& Organizational Change, 13(4), pp.492-519.

Kasznik,R., (1999). On the Association between Voluntary Disclosure and Earnings Management. Journal of Accounting Research, 37, pp.57-81.

Keung,E. and Shih,M.S.H., (2014). Measuring Discretionary Accruals: Are ROA-matched Models better than the Original Jones-type Models? Review of Accounting Studies, 19(2), pp.736768.

Kothari,S.P., Mizik,N. and Roychowdhury,S., (2016). Managing for the moment: The role of earnings management via real activities versus accruals in SEO valuation. The Accounting Review, 91(2), pp.559-586.

Kothari,S.P., Leone,A.J. and Wasley,C.E., (2005). Performance matched discretionary accrual measures. Journal of Accounting and Economics, 39(1), pp.163-197.

Lee,B.B. and Choi,B., (2002). Company size, auditor type, and earnings management. Journal of Forensic Accounting, 3(1), pp.27-50.

Lee,G. and Masulis,R.W., (2009). Seasoned equity offerings: Quality of accounting information and expected flotation costs. Journal of Financial Economics, 92(3), pp.443-469.

Lee,H.-A. and Choi,W.-W., (2016). Allowance for uncollectible accounts as a tool for earnings 
management: Evidence from South Korea. International Journal of Accounting \& Information Management.

Liu,H. and Lee,H.-A., (2019). The effect of corporate social responsibility on earnings management and tax avoidance in Chinese listed companies. International Journal of Accounting \& Information Management.

Lo,K., Ramos,F. and Rogo,R., (2017). Earnings management and annual report readability. Journal of Accounting and Economics, 63(1), pp.1-25.

Louis,H., (2004). Earnings management and the market performance of acquiring firms. Journal of Financial Economics, 74(1), pp.121-148.

Marquardt,C. and Zur,E., (2014). The Role of Accounting Quality in the M\&A Market. Management Science, 61(3), pp.604-623.

Martin,K.J., (1996). The method of payment in corporate acquisitions, investment opportunities, and management ownership. The Journal of Finance, 51(4), pp.1227-1246.

Moeller,S.B., Schlingemann,F.P. and Stulz,R.M., (2004). Firm Size and the Gains from Acquisitions. Journal of financial economics, 73(2), pp.201-228.

North,D.S. and O'Connell,B.T., (2002). Earnings Management and Mode of Payment in Takeovers. Document de travail, University of Richmond, Virginia.

Peasnell,K. V., Pope,P.F. and Young,S., (2005). Board monitoring and earnings management: Do outside directors influence abnormal accruals? Journal of Business, Finance, and Accounting, 32(7-8), pp.1311-1346.

Pham,H.Y., Chung,R.Y.M., Roca,E. and Bao,B.H., (2017). Discretionary accruals: Signalling or earnings management in Australia? Accounting and Finance.

La Porta,R., Lopez-de-Silanes,F. and Shleifer,A., (1999). Corporate ownership around the world. The Journal of Finance, 54(2), pp.471-517.

La Porta,R., Lopez-de-Silanes,F., Shleifer,A. and Vishny,R., (1997). Legal determinants of external capital. Journal of Finance, 52(3), pp.1131-1150.

Raman,K., Shivakumar,L. and Tamayo,A., (2013). Target's Earnings Quality and Bidders' Takeover Decisions. Review of Accounting Studies, 18(4), pp.1050-1087.

Rossi,S. and Volpin,P.F., (2004). Cross-Country Determinants of Mergers and Acquisitions. Journal of Financial Economics, 74(2), pp.277-304.

Roychowdhury,S., (2006). Earnings management through real activities manipulation. Journal of Accounting and Economics, 42, pp.335-370.

Seetharaman,A., Gul,F.A. and Lynn,S.G., (2002). Litigation risk and audit fees: Evidence from UK firms cross-listed on US markets. Journal of Accounting and Economics, 33(1), pp.91115 .

Skaife,H. a. and Wangerin,D.D., (2013). Target Financial Reporting Quality and M\&A Deals that go Bust. Contemporary Accounting Research, 30(2), pp.719-749.

Stulz,R., (1988). Managerial Control of Voting Rights: Financing Policies and the Market for Corporate Control. Journal of Financial Economics, 20, pp.25-54.

Stulz,R.M., Walkling,R.A. and Song,M.H., (1990). The Distribution of Target Ownership and the 
Division of Gains in Successful Takeovers. The Journal of Finance, 45(3), pp.817-833.

Vasilescu,C. and Millo,Y., (2016). Do Industrial and Geographic Diversifications have different effects on Earnings Management? Evidence from UK Mergers and Acquisitions. International Review of Financial Analysis, 46, pp.33-45.

Walker,M., (2013). How far can we trust earnings numbers? What research tells us about earnings management. Accounting and Business Research, 43(4), pp.445-481.

Wang,C., Tung,S., Chen-Chang,L., Lan-Fen,W. and Ching-Hui,L., (2010). Earnings management using asset sales. International Journal of Accounting \& Information Management.

Watts,R.L. and Zimmerman,J.L., (1990). Positive Accounting Theory: A Ten Year Perspective. The Accounting Review, 65, pp.131-156.

Xu,G., Xu,G., Ji,X. and Ji,X., (2016). Earnings management by top Chinese listed firms in response to the global financial crisis. International Journal of Accounting and Information Management, 24(3), pp.226-251.

Zalata,A.M., Tauringana,V. and Tingbani,I., (2018). Audit committee financial expertise, gender, and earnings management: Does gender of the financial expert matter? International Review of Financial Analysis, 55, pp.170-183.

Zang,A.Y., (2012). Evidence on the Trade-Off between Real Activities Manipulation and AccrualBased Earnings Management. The Accounting Review, 87(2), pp.675-703. 
Table (I) - Sample Collection and Data Process

\begin{tabular}{|c|c|c|c|}
\hline Request & Operator & Description & $\begin{array}{l}\text { Number of } \\
\text { firms }\end{array}$ \\
\hline Target Nation & Include & United Kingdom & 89,296 \\
\hline Acquirer Nation & Include & United Kingdom & 59,919 \\
\hline Date announced & Between & 1995 to 2013 & 39,386 \\
\hline Date Effective/Unconditional & Between & 1995 to 2013 & 35,593 \\
\hline Target public status & Include & Public & 2,397 \\
\hline Acquirer public status & Include & Public & 1,134 \\
\hline Target Macro Industry & Exclude & Financials & 792 \\
\hline Acquirer Macro Industry & Exclude & Financials & 704 \\
\hline Final Consideration Structure & Include & $\begin{array}{l}\text { Cash Only, Cash and Stock } \\
\text { Combination, Stock Only }\end{array}$ & 465 \\
\hline Deal Status Rollup & Include & Completed & 459 \\
\hline Percent of shares held at announcement & Between & Low to $50 \%$ & 448 \\
\hline $\begin{array}{l}\text { Percent of shares held owned after } \\
\text { transaction }\end{array}$ & Between & $50 \%$ to High & 278 \\
\hline Target Primary Stock Exchange & Exclude & AIM & 205 \\
\hline Deal Attitude & Include & Friendly, Hostile $^{\mathrm{a}}$ & 191 \\
\hline \multicolumn{4}{|c|}{$\begin{array}{l}\text { '14 deals were excluded from the sample since they do not meet the definition of a merger or acquisition according } \\
\text { to Thomson One banker as follows: (a) } 1 \text { deal classified as 'Unsolicited (U)' where the target's board has not giver } \\
\text { a recommendation. (b) } 1 \text { deal classified as 'Neutral (N)' where the target's board has nothing to do with th } \\
\text { transaction. (c) } 12 \text { deals classified as 'Not Applicable (X)' where the deal is a spinoff or split off. It is also worth } \\
\text { mentioning that the remaining } 191 \text { deals consist of } 5 \text { hostile deals while the remaining } 186 \text { deals are classified a } \\
\text { friendly deals. }\end{array}$} \\
\hline
\end{tabular}


Table (II) - Descriptive statistics for REM Proxies

\begin{tabular}{|c|c|c|c|c|c|c|c|c|c|c|c|}
\hline \multirow[b]{2}{*}{ Variable } & \multicolumn{3}{|c|}{ All Targets } & \multicolumn{3}{|c|}{ Stock-Only Targets } & \multicolumn{3}{|c|}{ Non-Stock Targets } & \multicolumn{2}{|c|}{$\begin{array}{c}\text { Difference } \\
\text { (Nonstock - } \\
\text { Stock) }\end{array}$} \\
\hline & $\begin{array}{c}\text { Mea } \\
\mathbf{n}\end{array}$ & $\underset{\mathbf{n}}{\text { Media }}$ & $\begin{array}{c}\text { Std.De } \\
\text { v. }\end{array}$ & $\begin{array}{c}\text { Mea } \\
\text { n }\end{array}$ & $\begin{array}{c}\text { Media } \\
\mathbf{n}\end{array}$ & $\begin{array}{c}\text { Std.De } \\
\text { v. }\end{array}$ & $\begin{array}{c}\text { Mea } \\
\mathbf{n}\end{array}$ & $\underset{\mathbf{n}}{\text { Media }}$ & $\begin{array}{c}\text { Std.D } \\
\text { ev }\end{array}$ & $\begin{array}{c}\text { Mean } \\
t- \\
\text { value }\end{array}$ & $\begin{array}{c}\text { Median } \\
\text { Wilcoxo } \\
n-Z\end{array}$ \\
\hline $\begin{array}{l}\text { ABN_CF } \\
\mathrm{O}\end{array}$ & $\begin{array}{c}0.00 \\
7\end{array}$ & 0.009 & 0.145 & $\begin{array}{c}0.00 \\
2\end{array}$ & 0.001 & 0.144 & $\begin{array}{c}0.01 \\
2\end{array}$ & 0.013 & 0.146 & 0.68 & 0.99 \\
\hline $\begin{array}{l}\text { ABN_DS } \\
\mathrm{X}\end{array}$ & $\begin{array}{c}- \\
0.01 \\
9\end{array}$ & -0.015 & 0.259 & $\begin{array}{c}0.04 \\
7\end{array}$ & -0.006 & 0.266 & $\begin{array}{c}- \\
0.05 \\
6\end{array}$ & -0.035 & 0.246 & $\begin{array}{c}- \\
3.80^{*} \\
* *\end{array}$ & $\begin{array}{c}- \\
2.75 * * *\end{array}$ \\
\hline $\begin{array}{l}\text { ABN_PR } \\
\text { D }\end{array}$ & $\begin{array}{c}- \\
0.03 \\
6\end{array}$ & 0.000 & 0.289 & $\begin{array}{c}- \\
0.06 \\
2\end{array}$ & -0.034 & 0.236 & $\begin{array}{c}- \\
0.01 \\
7\end{array}$ & 0.032 & 0.320 & 1.37 & $2.66 * * *$ \\
\hline $\begin{array}{l}\text { Observatio } \\
\mathrm{ns}\end{array}$ & 341 & 341 & 341 & 138 & 138 & 138 & 203 & 203 & 203 & & \\
\hline
\end{tabular}

Table (I) reports mean and median residuals for the REM proxies for the overall sample of targets. It also reports the difference in mean ( $\mathrm{t}$-test) and median (Wilcoxon signed-rank test) real earnings management between targets acquired in stock-financed deals and targets acquired in deals financed using cash and/or a mixed payment consideration structure.

*Significant at the $10 \%$ level. **Significant at the 5\% level. *** Significant at the $1 \%$ level. The reported REM proxies are winsorized at the top and bottom 1 percent to avoid extreme observations due to noisy estimation. Abnormal cash flows from operations, abnormal discretionary expenses, and abnormal production costs are estimated residuals using models developed by Dechow et al. (1998) and as implemented by Roychowdhury (2006). Abnormal cash flows from operations and abnormal discretionary expenses are multiplied by $(-1)$ to allow all real earnings management measures to have the same interpretation. 
Table (III)- Regression Analysis of various REM proxies on EVENT_YEAR Dummies and Controls Panel A: Regression Analysis of Abnormal Cash Flows from Operations (ABN_CFO) on EVENT_YEAR Dummies and Controls

\begin{tabular}{|c|c|c|c|c|}
\hline Dependent Variable & & Abnormal Cash Flc & from Operations (ABN_c & \\
\hline Variable & $\begin{array}{l}\text { All Targets } \\
\text { (1) }\end{array}$ & $\begin{array}{c}\text { Stock-only Targets } \\
\text { (2) }\end{array}$ & $\begin{array}{c}\text { Mixed-payment Targets } \\
\text { (3) }\end{array}$ & $\begin{array}{c}\text { Cash-only Targets } \\
\text { (4) }\end{array}$ \\
\hline INTERCEPT & $0.589 * * *$ & $0.153 * * *$ & -0.035 & $0.603 * * *$ \\
\hline & $(4.65)$ & $(2.87)$ & $(-0.21)$ & $(8.00)$ \\
\hline EVENT_YEAR $^{-1}$ & -0.002 & 0.014 & -0.012 & -0.012 \\
\hline & $(-0.18)$ & $(0.47)$ & $(-0.66)$ & $(-0.42)$ \\
\hline SIZE & 0.0001 & 0.003 & -0.010 & -0.004 \\
\hline & $(0.00)$ & $(0.20)$ & $(-0.56)$ & $(-0.17)$ \\
\hline MTB & -0.001 & $-0.005 * *$ & 0.004 & -0.003 \\
\hline & $(-0.87)$ & $(-2.18)$ & $(1.42)$ & $(-0.49)$ \\
\hline ROA & $-0.077 * * *$ & $-0.062 * * *$ & -0.019 & $-0.054 * * *$ \\
\hline & $(-7.17)$ & $(-4.48)$ & $(-1.08)$ & $(-3.28)$ \\
\hline AEM_CTRL & $0.074 * * *$ & $0.081 * * *$ & $0.056 * * *$ & $0.059 * *$ \\
\hline & $(7.01)$ & $(4.48)$ & $(3.86)$ & $(2.14)$ \\
\hline SGROWTH & $0.065 * * *$ & $0.048 * * *$ & 0.026 & 0.043 \\
\hline & (3.99) & $(2.78)$ & $(0.71)$ & $(0.84)$ \\
\hline Observations & 345 & 144 & 104 & 97 \\
\hline Adjusted R2 & 0.458 & 0.498 & 0.299 & 0.711 \\
\hline F-Statistic & $5.92 * * *$ & $4.23 * * *$ & $2.02 * * *$ & $6.13 * * *$ \\
\hline Year dummies & Yes & Yes & Yes & Yes \\
\hline Industry dummies & Yes & Yes & Yes & Yes \\
\hline
\end{tabular}

Panel B: Regression Analysis of Abnormal Discretionary Expenses (ABN_DSX) on EVENT_YEAR Dummies and Controls

\begin{tabular}{|c|c|c|c|c|}
\hline \multirow{2}{*}{$\begin{array}{l}\text { Dependent Variable } \\
\text { Variable }\end{array}$} & \multicolumn{4}{|c|}{ Abnormal Discretionary Expenses (ABN_DSX) } \\
\hline & $\begin{array}{l}\text { All Targets } \\
\text { (1) }\end{array}$ & $\begin{array}{c}\text { Stock-only Targets } \\
(2)\end{array}$ & $\begin{array}{c}\text { Mixed-payment Targets } \\
\text { (3) }\end{array}$ & $\begin{array}{c}\text { Cash-only Targets } \\
\text { (4) }\end{array}$ \\
\hline \multirow[t]{2}{*}{ INTERCEPT } & 0.080 & 0.028 & 0.054 & 0.020 \\
\hline & $(0.69)$ & $(0.36)$ & $(0.33)$ & $(0.15)$ \\
\hline \multirow[t]{2}{*}{ EVENT_YEAR $^{-1}$} & -0.003 & $0.084 * *$ & -0.052 & -0.056 \\
\hline & $(-0.14)$ & $(2.66)$ & $(-1.11)$ & $(-0.86)$ \\
\hline \multirow[t]{2}{*}{ SIZE } & $-0.046 *$ & $-0.093 * * *$ & -0.038 & 0.044 \\
\hline & $(-1.96)$ & $(-3.28)$ & $(-0.82)$ & $(0.40)$ \\
\hline \multirow[t]{2}{*}{ MTB } & -0.002 & $0.008^{*}$ & -0.017 & -0.013 \\
\hline & $(-0.50)$ & $(1.71)$ & $(-1.15)$ & $(-1.34)$ \\
\hline \multirow[t]{2}{*}{ ROA } & 0.002 & 0.046 & 0.037 & -0.001 \\
\hline & $(0.06)$ & $(1.22)$ & $(0.69)$ & $(-0.02)$ \\
\hline \multirow[t]{2}{*}{ AEM_CTRL } & $0.052 * * *$ & -0.002 & $0.075^{* *}$ & $0.056 * *$ \\
\hline & $(2.62)$ & $(-0.09)$ & $(2.47)$ & $(2.18)$ \\
\hline \multirow[t]{2}{*}{ SGROWTH } & $-0.071 *$ & -0.052 & $-0.245^{* *}$ & $-0.192 * *$ \\
\hline & $(-1.86)$ & $(-1.28)$ & $(-2.41)$ & $(-2.24)$ \\
\hline Observations & 341 & 138 & 100 & 103 \\
\hline Adjusted $R^{2}$ & 0.104 & 0.256 & 0.384 & 0.469 \\
\hline F-Statistic & $1.65 * * *$ & $2.10 * * *$ & $2.44 * * *$ & $2.96^{* * *}$ \\
\hline Year dummies & Yes & Yes & Yes & Yes \\
\hline Industry dummies & Yes & Yes & Yes & Yes \\
\hline \multicolumn{5}{|c|}{$\begin{array}{l}\text { Panel C: Regression Analysis of Abnormal Production Costs (ABN_PRD) on EVENT_YEAR Dummies and } \\
\text { Controls }\end{array}$} \\
\hline Dependent Variable & \multicolumn{4}{|c|}{ Abnormal Production Costs (ABN_PRD) } \\
\hline Variable & $\begin{array}{c}\text { All } \\
\text { Targets } \\
(1)\end{array}$ & $\begin{array}{l}\text { Stock-only Targets } \\
\text { (2) }\end{array}$ & $\begin{array}{c}\text { Mixed-payment } \\
\text { Targets } \\
(3)\end{array}$ & $\begin{array}{l}\text { Cash-only Targets } \\
\text { (4) }\end{array}$ \\
\hline INTERCEPT & $\begin{array}{l}0.245 * * * \\
(2.73)\end{array}$ & $\begin{array}{l}0.031 \\
(0.35)\end{array}$ & $\begin{array}{l}0.107 \\
(0.74)\end{array}$ & $\begin{array}{l}0.192 \\
(1.36)\end{array}$ \\
\hline EVENT_YEAR $^{-1}$ & $\begin{array}{l}-0.058 \\
(-1.62)\end{array}$ & $\begin{array}{l}-0.087 \\
(-0.95)\end{array}$ & $\begin{array}{l}0.002 \\
(0.05)\end{array}$ & $\begin{array}{l}-0.044 \\
(-0.70)\end{array}$ \\
\hline SIZE & -0.018 & $-0.068^{*}$ & -0.064 & -0.032 \\
\hline
\end{tabular}




\begin{tabular}{|c|c|c|c|c|}
\hline \multirow{3}{*}{ МТВ } & $(-0.69)$ & $(-1.87)$ & $(-1.17)$ & $(-0.24)$ \\
\hline & - & $-0.008 *$ & $-0.031 *$ & -0.015 \\
\hline & $\begin{array}{c}0.019 * * * \\
(-3.82)\end{array}$ & $(-1.76)$ & $(-2.01)$ & $(-1.32)$ \\
\hline \multirow[t]{2}{*}{ ROA } & - & $-0.053 * *$ & -0.019 & $-0.108 * *$ \\
\hline & $\begin{array}{c}0.099 * * * \\
(-4.41)\end{array}$ & $(-2.05)$ & $(-0.40)$ & $(-2.28)$ \\
\hline \multirow[t]{2}{*}{ AEM_CTRL } & $0.067 * * *$ & -0.018 & $0.064^{*}$ & $0.113 * *$ \\
\hline & $(2.75)$ & $(-0.46)$ & $(1.87)$ & $(2.24)$ \\
\hline \multirow[t]{2}{*}{ SGROWTH } & 0.029 & -0.014 & 0.057 & 0.119 \\
\hline & $(0.87)$ & $(-0.41)$ & $(0.41)$ & $(0.91)$ \\
\hline Observations & 341 & 142 & 102 & 97 \\
\hline Adjusted $R^{2}$ & 0.277 & 0.321 & 0.412 & 0.446 \\
\hline F-Statistic & $3.14 * * *$ & $2.52 * * *$ & $2.64 * * *$ & $2.68 * * *$ \\
\hline Year dummies & Yes & Yes & Yes & Yes \\
\hline Industry dummies & Yes & Yes & Yes & Yes \\
\hline
\end{tabular}

The dependent variable is Abnormal Cash Flows from Operations (ABN_CFO), Abnormal Discretionary Expenses (ABN_DSX), Abnormal production costs (ABN_PRD) in Panels A, B and C, respectively. The main independent variable of interest is $E V E N T_{-} Y E A R^{-1}$, which is an Indicator variable that takes the value of 1 for the first year preceding the acquisition and zero otherwise. SIZE is the natural logarithm of market capitalization. MTB is Marketto-book ratio calculated as market value of common equity divided by the book value of common equity. $R O A$ is return on assets calculated as net income before extraordinary items divided by lagged total assets. AEM_CTRL is discretionary working capital accruals estimated using the cross-sectional modified Jones model. SGROWTH is one-year growth in sales. The pooled sample includes observations for $131 \mathrm{UK}$ target firms over a three-year event period ranging from 341 observations to 345 observations depending on the REM dependent variable used. This final sample which is used in the estimation of coefficients, is different than the initial pooled sample observations of 393 due to missing data on some control variables in some event years in addition to missing data required to calculate REM proxies for some firm-year observations. All variables are winsorized at the top and bottom 1 percentile. $(* * *, * *, *$ represent statistical significance at $1 \%, 5 \%$ and $10 \%$ respectively). T-statistics (in parentheses below the coefficients) are calculated using Rogers (1993) clustered robust standard errors clustered at the firm 'target' level and are robust to both heteroskedasticity and serial auto-correlation (Petersen, 2009). Industry fixedeffects and year fixed-effects are not reported for sake of brevity. 
Table (IV) - Fixed-effect regression analysis of abnormal discretionary expenses (ABN_DSX)

\begin{tabular}{|c|c|c|c|c|}
\hline \multirow{2}{*}{$\begin{array}{l}\text { Dependent Variable } \\
\text { Variable }\end{array}$} & \multicolumn{4}{|c|}{ Abnormal Discretionary Expenses (ABN_DSX) } \\
\hline & $\begin{array}{l}\text { All Targets } \\
\text { (1) }\end{array}$ & $\begin{array}{c}\text { Stock-only } \\
\text { Targets } \\
\text { (2) }\end{array}$ & $\begin{array}{c}\text { Mixed-payment } \\
\text { Targets } \\
\text { (3) }\end{array}$ & $\begin{array}{c}\text { Cash-only } \\
\text { Targets } \\
\text { (4) }\end{array}$ \\
\hline INTERCEPT & $\begin{array}{l}0.124 \\
(1.03)\end{array}$ & $\begin{array}{l}0.083 \\
(0.73)\end{array}$ & $\begin{array}{l}0.146 \\
(0.58)\end{array}$ & $\begin{array}{l}0.118 \\
(0.14)\end{array}$ \\
\hline EVENT_YEAR $^{-1}$ & $\begin{array}{l}-0.037 \\
(-1.35)\end{array}$ & $\begin{array}{l}0.148 * * * \\
(3.73)\end{array}$ & $\begin{array}{l}-0.014 \\
(-0.07)\end{array}$ & $\begin{array}{l}0.020 \\
(0.08)\end{array}$ \\
\hline SIZE & $\begin{array}{c}-0.068^{*} \\
(-1.86)\end{array}$ & $\begin{array}{l}-0.003 \\
(-0.07)\end{array}$ & $\begin{array}{l}0.076 \\
(0.70)\end{array}$ & $\begin{array}{l}-0.143^{*} \\
(-1.85)\end{array}$ \\
\hline MTB & $\begin{array}{l}-0.003 \\
(-1.24)\end{array}$ & $\begin{array}{c}0.0001 \\
(0.08)\end{array}$ & $\begin{array}{c}-0.010 * * \\
(-2.51)\end{array}$ & $\begin{array}{l}-0.009 \\
(-1.43)\end{array}$ \\
\hline ROA & $\begin{array}{l}0.010 \\
(0.69)\end{array}$ & $\begin{array}{l}0.031 \\
(1.42)\end{array}$ & $\begin{array}{l}0.033 \\
(1.06)\end{array}$ & $\begin{array}{l}-0.016 \\
(-0.65)\end{array}$ \\
\hline AEM_CTRL & $\begin{array}{l}0.087 \\
(1.47)\end{array}$ & $\begin{array}{l}-0.204 * \\
(-1.88)\end{array}$ & $\begin{array}{l}0.524 * * * \\
(3.54)\end{array}$ & $\begin{array}{l}0.094 \\
(1.17)\end{array}$ \\
\hline SGROWTH & $\begin{array}{c}-0.055^{* * *} \\
(-2.93)\end{array}$ & $\begin{array}{l}-0.022 \\
(-0.95)\end{array}$ & $\begin{array}{l}-0.084 \\
(-1.17)\end{array}$ & $\begin{array}{c}-0.128 * * * \\
(-3.24)\end{array}$ \\
\hline Observations & 341 & 138 & 100 & 103 \\
\hline Firm fixed effects & Yes & Yes & Yes & Yes \\
\hline Time dummies & Yes & Yes & Yes & Yes \\
\hline F-Statistic & $8.90 * * *$ & $8.58 * * *$ & $7.77 * * *$ & $17.01 * * *$ \\
\hline
\end{tabular}

This table presents FE regression estimates for the pooled dataset, which includes 341 observations for 131 UK target firms over a three-year event period. The dependent variable is abnormal discretionary expenses (ABN_DSX) in all these models, while the main independent variable of interest is EVENT_YEAR ${ }^{-1}$ which is an indicator variable that takes the value of 1 for the first year preceding the acquisition and zero otherwise. SIZE is the natural logarithm of market capitalization. MTB is Market-to-book ratio calculated as market value of common equity divided by the book value of common equity. ROA is return on assets calculated as net income before extraordinary items divided by lagged total assets. AEM_CTRL is lagged discretionary current accruals as estimated from the performance adjusted accruals model (Kothari et al., 2005). SGROWTH is one-year growth in sales. All variables are winsorized at the top and bottom 1 percentile. (***,**,* represent statistical significance at $1 \%, 5 \%$ and $10 \%$ respectively). T-statistics (in parentheses below the coefficients) are calculated using Rogers (1993) clustered robust standard errors clustered at the firm 'target' level and are robust to both heteroskedasticity and serial auto-correlation (Petersen, 2009). All models include an intercept and firm-fixed effects. Time dummies are included within the regression models and are not reported for sake of brevity. 
Table (V)- Heckman two-step self-selection analysis of abnormal Discretionary Expenses on EVENT_YEAR dummy

\begin{tabular}{|c|c|c|c|c|}
\hline \multirow{2}{*}{$\begin{array}{l}\text { Dependent Variable } \\
\text { Variable }\end{array}$} & \multicolumn{4}{|c|}{ Abnormal Discretionary Expenses (ABN_DSX) } \\
\hline & $\begin{array}{l}\text { All Targets } \\
\text { (1) }\end{array}$ & $\begin{array}{c}\text { Stock-only Targets } \\
\text { (2) }\end{array}$ & $\begin{array}{c}\text { Mixed-payment Targets } \\
\text { (3) }\end{array}$ & $\begin{array}{c}\text { Cash-only Targets } \\
\text { (4) }\end{array}$ \\
\hline \multirow[t]{2}{*}{ INTERCEPT } & 0.088 & 0.060 & 0.071 & 0.100 \\
\hline & $(0.76)$ & $(0.76)$ & $(0.44)$ & $(0.91)$ \\
\hline \multirow[t]{2}{*}{ EVENT_YEAR $^{-1}$} & -0.004 & $0.081 * *$ & -0.052 & -0.079 \\
\hline & $(-0.21)$ & $(2.68)$ & $(-1.11)$ & $(-1.52)$ \\
\hline \multirow[t]{2}{*}{ SIZE } & $-0.049 * *$ & $-0.077 * * *$ & -0.039 & 0.064 \\
\hline & $(-1.99)$ & $(-3.23)$ & $(-0.84)$ & $(0.71)$ \\
\hline \multirow[t]{2}{*}{ MTB } & -0.002 & 0.008 & -0.017 & $-0.016^{* *}$ \\
\hline & $(-0.53)$ & (1.66) & $(-1.12)$ & $(-2.12)$ \\
\hline \multirow[t]{2}{*}{ ROA } & 0.002 & 0.044 & 0.034 & -0.004 \\
\hline & $(0.08)$ & $(1.26)$ & $(0.60)$ & $(-0.09)$ \\
\hline \multirow[t]{2}{*}{ AEM_CTRL } & $0.052 * *$ & -0.004 & $0.076 * *$ & $0.045^{*}$ \\
\hline & $(2.60)$ & $(-0.22)$ & $(2.46)$ & $(1.83)$ \\
\hline \multirow[t]{2}{*}{ SGROWTH } & $-0.070 *$ & -0.055 & $-0.238 * *$ & $-0.167 * *$ \\
\hline & $(-1.85)$ & $(-1.47)$ & $(-2.65)$ & $(-2.13)$ \\
\hline \multirow[t]{2}{*}{ IMR } & 0.009 & $-0.046^{*}$ & 0.014 & $0.082 * *$ \\
\hline & $(-0.51)$ & $(-1.93)$ & $(0.40)$ & $(2.45)$ \\
\hline Observations & 341 & 138 & 100 & 103 \\
\hline Adjusted $R^{2}$ & 0.263 & 0.524 & 0.653 & 0.763 \\
\hline F-Statistic & $1.64 * * *$ & $2.33 * * *$ & $2.35 * * *$ & $3.77 * * *$ \\
\hline Year dummies & Yes & Yes & Yes & Yes \\
\hline Industry dummies & Yes & Yes & Yes & Yes \\
\hline
\end{tabular}

The dependent variable is abnormal discretionary expenses (ABN_DSX) in all these models. The main independent variable of interest is EVENT_YEAR ${ }^{-1}$ which is an indicator variable that takes the value of 1 for the first year preceding the acquisition, and zero otherwise. SIZE is the natural logarithm of market capitalization. $M T B$ is Market-to-book ratio calculated as market value of common equity divided by the book value of common equity. $R O A$ is return on assets calculated as net income before extraordinary items divided by lagged total assets. AEM_CTRL is lagged discretionary working capital accruals estimated using the cross-sectional modified Jones model. SGROWTH is one-year growth in sales. IMR is the inverse Mills ratio estimated from a probit model's coefficients on the likelihood of becoming an M\&A target. The pooled sample includes 341 observations for 131 UK target firms over a three-year event period. This final sample which is used in the estimation of coefficients is different than the initial pooled sample observations of 393 due to missing data on some control variables in some event years in addition to missing data required to calculate abnormal discretionary expenses for some firm-year observations. All variables are winsorized at the top and bottom 1 percentile. (***, **, * represent statistical significance at 1\%,5\% and 10\% respectively). T-statistics (in parentheses below the coefficients) are calculated using Rogers (1993) clustered robust standard errors clustered at the firm 'target' level and are robust to both heteroskedasticity and serial auto-correlation (Petersen, 2009). Industry fixed-effects and year fixed-effects are not reported for sake of brevity. 